University of Nebraska - Lincoln

DigitalCommons@University of Nebraska - Lincoln

2000

\title{
Development and Demonstration of RNA Isolation and RT-PCR Procedures to Detect Escherichia coli 0157:H7 Gene Expression on Beef Carcass Surfaces
}

E. D. Berry

USDA-ARS, elaine.berry@ars.usda.gov

Follow this and additional works at: https://digitalcommons.unl.edu/hruskareports

Berry, E. D., "Development and Demonstration of RNA Isolation and RT-PCR Procedures to Detect Escherichia coli 0157:H7 Gene Expression on Beef Carcass Surfaces" (2000). Roman L. Hruska U.S. Meat Animal Research Center. 220.

https://digitalcommons.unl.edu/hruskareports/220

This Article is brought to you for free and open access by the U.S. Department of Agriculture: Agricultural Research Service, Lincoln, Nebraska at DigitalCommons@University of Nebraska - Lincoln. It has been accepted for inclusion in Roman L. Hruska U.S. Meat Animal Research Center by an authorized administrator of DigitalCommons@University of Nebraska - Lincoln. 


\title{
Development and demonstration of RNA isolation and RT-PCR procedures to detect Escherichia coli 0157:H7 gene expression on beef carcass surfaces
}

\author{
E.D. Berry \\ USDA, ARS, Roman L. Hruska U.S. Meat Animal Research Center, Clay Center, NE, USA \\ 506/2000: received 6 January 2000, revised 29 March 2000 and accepted 25 May 2000 \\ E.D. BERRY. 2000. Preventing the development of pathogen resistance to processing and \\ preservation techniques will require an understanding of the genetic mechanisms that \\ pathogens use in situ to adapt and develop tolerance to stresses they encounter in the food \\ environment. RNA isolation and reverse-transcription (RT)-PCR protocols were developed \\ as tools to detect gene expression in bacteria on beef carcass surfaces. The utility of these \\ procedures was demonstrated by detecting the expression of a selectively-inducible green \\ fluorescent protein (GFP) gene in a plasmid-transformed strain of Escherichia coli O157:H7 \\ inoculated onto beef carcass surface tissue. These procedures should serve as useful tools \\ for studying the genetic responses of bacteria when exposed to antimicrobial interventions \\ applied to food animal carcasses.
}

\section{INTRODUCTION}

In recent years, food microbiologists have paid increased attention to adaptive stress responses of bacteria, and data are accumulating which indicate that the effects of these responses can be significant for food preservation and safety. While the physiological and genetic mechanisms of these adaptive responses are not fully understood, it is clear that when exposed to a mild or sub-lethal dose of a stress, micro-organisms may adapt to the stress, thus developing resistance to stronger doses. For example, the acquisition of increased heat resistance by food-borne pathogenic micro-organisms as a result of prior heat stress has been well documented (Mackey and Derrick 1986, 1987; Bunning et al. 1990; Farber and Brown 1990). As another example, adaptation to acidic conditions can improve the survival of E. coli O157:H7, Listeria monocytogenes and Salmonella typhimurium in foods that are preserved by low $\mathrm{pH}$ and acids, including cheeses and other fermented milk products, fermented sausage and apple cider (Leyer and Johnson 1992; Leyer et al. 1995; Gahan et al. 1996). It has also been demonstrated that bacterial exposure and subsequent adaptation to one stress may confer increased resis-

Correspondence to: Dr E.D. Berry, USDA, ARS, Roman L. Hruska U.S. Meat Animal Research Center, PO Box 166, Clay Center, NE 68933-0166, USA (e-mail: berry@email.marc.usda.gov).

Mention of trade names or commercial products in this article is solely for the purpose of providing specific information and does not imply recommendation or endorsement by the US Department of Agriculture. tance to other, different stresses. For instance, Leyer and Johnson (1993) found that acid-adapted Salm. typhimurium exhibited increased tolerance to heat, salt and an activated lactoperoxidase system, which are used to inhibit microbial growth in foods. Likewise, sub-lethal heat shocks increased E. coli $\mathrm{O} 157: \mathrm{H7}$ acid tolerance (Wang and Doyle 1998). As the natural environment of bacteria is typically low in nutrients and is often otherwise adverse to rapid growth, it is likely that most micro-organisms are in the stationary phase of growth as they arrive as contaminants in food (Rees et al. 1995). As induction of stationary-phase growth causes bacteria to be more resistant to a variety of stresses, including heat, acid and osmotic stress (Hengge-Aronis et al. 1991; McCann et al. 1991; Arnold and Kaspar 1995; Cheville et al. 1996), such contaminants may arrive predisposed to survive in foods despite the use of inactivation processes or the presence of antimicrobial preservatives. In addition, environmental stresses, such as those imposed as preservative barriers in foods, may not only induce stress tolerance and/or stationary phase in microbial pathogens, but may also enhance virulence and enable survival in the gastrointestinal tract and in macrophages, thus increasing the probability that they may survive in the host and ultimately cause disease (as reviewed by Mekalanos 1992; Rees et al. 1995; Archer 1996). These concepts, and the need for greater knowledge of adaptive stress responses of foodborne pathogenic bacteria and their implications for food preservation and safety, have been discussed further by Knøchel and Gould (1995), Archer (1996) and Sheridan and McDowell (1998). 
An understanding of the molecular mechanisms that bacteria use to develop tolerance to food preservation techniques is necessary in order to discover methods of preventing these occurrences. Of importance to this endeavour will be the ability to detect bacterial gene expression in situ during or following antimicrobial treatment of a food product. In view of a particular interest in the understanding of how pathogens respond to the antimicrobial interventions used to decontaminate beef carcasses, the objective of this work was to develop and demonstrate RNA isolation and RT-PCR protocols for detecting bacterial gene expression on carcass surfaces.

\section{MATERIALS AND METHODS}

\section{Organism and inocula preparation}

Escherichia coli O157:H7 T1-1 was provided by Dr G. R. Siragusa (Roman L. Hruska U.S. Meat Animal Research Center). The strain was derived by transformation of $E$. coli O157:H7 B6914-MS1 with the plasmid pBAD-GFPuv. This plasmid contains the optimized green fluorescent protein gene (GFPuv) in the pBAD18 vector, under the control of the araC-P $\mathrm{P}_{\mathrm{BAD}}$ promoter system (Crameri et al. 1996; Guzman et al. 1995). Expression from the $\mathrm{P}_{\mathrm{BAD}}$ promoter is induced by arabinose and is repressed to very low levels by the presence of glucose (Guzman et al. 1995). This strain was kept at $-20^{\circ} \mathrm{C}$ in $20 \%$ glycerol. An aliquot of the frozen stock was inoculated into Luria Bertani broth (LB; Difco) containing $100 \mu \mathrm{g} \mathrm{ml}^{-1}$ ampicillin (for plasmid maintenance) and $0.5 \%(\mathrm{v} / \mathrm{v})$ arabinose, and incubated for $18 \mathrm{~h}$ at $37^{\circ} \mathrm{C}$ with shaking at $50 \mathrm{rev} \mathrm{min}^{-1}$ prior to experiments. To prepare the inocula, cells from $10 \mathrm{ml}$ of this culture were collected by centrifugation $(16000 \mathrm{~g}, 3 \mathrm{~min})$, washed twice and resuspended in $5 \mathrm{ml} \mathrm{LB}$ broth. Washed cells were enumerated by serial dilution in buffered peptone water (Difco), plating in duplicate onto LB agar plates containing $100 \mu \mathrm{g} \mathrm{ml}{ }^{-1}$ ampicillin and $0.5 \%(\mathrm{v} / \mathrm{v})$ arabinose, and counting colonies following incubation for $24 \mathrm{~h}$ at $37^{\circ} \mathrm{C}$.

\section{Beef tissue inoculation and sampling}

Lean beef carcass surface tissue (BCT) was obtained from the cutaneous trunci of pre-washed, pre-rigor carcasses shortly after slaughter at a local cow/bull processing facility. The BCT was transported immediately to the laboratory, vacuum-packaged and frozen at $-20^{\circ} \mathrm{C}$ for at least 1 week prior to use. For each of three replicates of the experiment performed on three separate days, BCT from one animal was thawed overnight at $4{ }^{\circ} \mathrm{C}$ prior to inoculation.
For each experimental replicate, two $10 \times 20 \mathrm{~cm}$ samples were aseptically excised from the thawed BCT and placed in separate sterile pans, with the external side facing up. In addition, duplicate $2 \times 2 \mathrm{~cm}$ samples were aseptically excised from the remaining BCT to serve as uninoculated control samples. A $2 \mathrm{ml}$ aliquot of the E. coli O157:H7 T11 inoculum was spread evenly over the surface of each 10 $\times 20 \mathrm{~cm}$ BCT sample (target cell level was approximately $10^{6} \mathrm{cfu}^{-2}$ ). The inoculated BCT was allowed to stand for $15 \mathrm{~min}$. Each BCT sample was then treated with $5 \mathrm{ml}$ of either $0.5 \%$ arabinose or $0.5 \%$ glucose to induce or repress gfpuv expression, respectively. The sterile sugar solutions were applied by spraying the compounds evenly over the surface with hand-held spray bottles. Following these applications, excess fluid was drained from the meat surface for $15 \mathrm{~s}$, then the pans containing the BCT were covered with sterile trays and allowed to incubate at room temperature (approximately $22^{\circ} \mathrm{C}$ ) for $60 \mathrm{~min}$. At $60 \mathrm{~min}$, duplicate $2 \times 2 \mathrm{~cm}$ samples were aseptically excised from both arabinose- and glucose-treated samples. Immediately following excision, all $2 \times 2 \mathrm{~cm}$ BCT samples were frozen in liquid nitrogen and stored at $-70^{\circ} \mathrm{C}$ for RNA isolation.

\section{RNA isolation}

Total RNA was isolated using TRI Reagent (Sigma) with modifications to the manufacturer's recommended procedures for RNA isolation from tissues. Individual frozen 2 $\times 2 \mathrm{~cm}$ BCT samples were quickly added to $10 \mathrm{ml}$ TRI Reagent in a sterile $50 \mathrm{ml}$ tube. Samples were placed in a $65^{\circ} \mathrm{C}$ water-bath to thaw for $10 \mathrm{~min}$. Following thawing, incubation at $65^{\circ} \mathrm{C}$ was continued for $10 \mathrm{~min}$, with vigorous vortexing for $10 \mathrm{~s}$ at $2.5 \mathrm{~min}$ intervals. Samples were centrifuged $\left(750 \mathrm{~g}, 10 \mathrm{~min}, 4^{\circ} \mathrm{C}\right)$ to remove insoluble material; floating fatty material was removed and clarified supernatant fluids were transferred to fresh tubes. Chloroform (2 $\mathrm{ml}$ ) was added to each of the tubes, which were shaken vigorously for $15 \mathrm{~s}$ and allowed to stand at room temperature for $15 \mathrm{~min}$. The tubes were shaken again, then centrifuged at $12000 \mathrm{~g}$ at $4{ }^{\circ} \mathrm{C}$ for $15 \mathrm{~min}$. The upper aqueous phases were transferred to fresh tubes, $5 \mathrm{ml}$ isopropanol added and mixed, and the tubes allowed to stand at room temperature for $10 \mathrm{~min}$. Samples were centrifuged at $12000 \mathrm{~g}$ at $4{ }^{\circ} \mathrm{C}$ for $30 \mathrm{~min}$. Supernatant fluids were removed and the RNA pellets were washed with $10 \mathrm{ml}$ ice-cold $75 \%$ ethanol. The samples were vortexed and held on ice for $30 \mathrm{~min}$ prior to centrifugation $\left(12000 \mathrm{~g}, 30 \mathrm{~min}, 4^{\circ} \mathrm{C}\right)$ and removal of the ethanol. The tubes were inverted and the RNA pellets were allowed to air-dry for $10 \mathrm{~min}$. The RNA pellets were dissolved in $100 \mu \mathrm{l}$ diethyl pyrocarbonate (DEPC)-treated water. The extracted RNA was treated with DNase I (1 U per $\mu \mathrm{g}$ RNA; Gibco BRL); total RNA concentrations were estimated based on absorbance at $260 \mathrm{~nm}$, and confirmed 
by comparison of ethidium bromide fluorescence intensities of $5 \mu \mathrm{g}$ total RNA of each sample in a $1.5 \%$ agarose Trisborate-EDTA gel (Sambrook et al. 1989). The RNA samples were stored at $-70{ }^{\circ} \mathrm{C}$.

\section{RT-PCR procedure}

Primers for PCR were designed from the GFPuv DNA sequence (GenBank accession U62637) using OLIGO Primer Analysis software (Version 5.0; National Biosciences, Inc., Plymouth, MN, USA). The sequences of the primers $\left(5^{\prime}\right.$ to $\left.3^{\prime}\right)$ used in the first-step PCR were GFP7 (TCAATGCTTTTCCCGTTATCC) and GFP-8 (ATCCATGCCATGTGTAATCCC); this primer pair amplifies a 499 bp fragment of the GFPuv gene, corresponding to nucleotides 1548-2046 of the plasmid sequence. The sequences of the primers used in the second-step PCR were GFP-9 (GCCATGCCCGAA GGTTATGTA) and GFP-10 (TTCGAAAGGGCAG ATTGTGTC); this primer pair amplifies a 368 bp fragment corresponding to nucleotides 1603-1970 within the first-step amplicon. Primer GFP-8 was used for cDNA synthesis in RT reactions.

cDNA was synthesized using RETROscript reagents (Ambion Inc., Austin, TX, USA). The $20 \mu \mathrm{l}$ RT reactions contained the following: $1 \times$ alternate first-strand buffer (Ambion; $50 \mathrm{mmoll}^{-1}$ Tris $\mathrm{HCl}$ (pH 8.3), $75 \mathrm{mmoll}^{-1}$ $\mathrm{KCl}, 3 \mathrm{mmoll}^{-1} \mathrm{MgCl}_{2}, 5 \mathrm{mmoll}^{-1}$ dithiothreitol), 500 $\mu \mathrm{mol} \mathrm{l}^{-1}$ each dNTP, $5 \mu \mathrm{mol} \mathrm{l}^{-1}$ primer GFP-8, $10 \mathrm{U}$ placental RNase inhibitor, $100 \mathrm{U}$ M-MLV reverse transcriptase and $500 \mathrm{ng}$ total RNA. Reaction mixtures containing the total RNA, primer and dNTPs were heated at $85^{\circ} \mathrm{C}$ for $3 \mathrm{~min}$ prior to cooling on ice and adding the buffer, RNase inhibitor and reverse transcriptase. The RT reactions were carried out using a PTC-100 thermal cycler (MJ Research, Inc., Watertown, MA, USA) by incubation at 42 ${ }^{\circ} \mathrm{C}$ for $1 \mathrm{~h}$, followed by heating at $92^{\circ} \mathrm{C}$ for $10 \mathrm{~min}$. The cDNA was stored at $-70^{\circ} \mathrm{C}$.

Both first- and second-step PCR reactions $(50 \mu \mathrm{l})$ contained the following: $20 \mathrm{mmol}^{-1}$ Tris $\mathrm{HCl}(\mathrm{pH} 8.4), 50$ $\mathrm{mmol}^{-1} \mathrm{KCl}, 1.5 \mathrm{mmoll}^{-1} \mathrm{MgCl}_{2}, 0.2 \mathrm{mmoll}^{-1}$ each dNTP, $0.4 \mu \mathrm{mol}^{-1}$ each primer and $1.25 \mathrm{U}$ Taq DNA polymerase (Gibco BRL). A $5 \mu \mathrm{l}$ aliquot of the RT reaction mixtures was added to the first-step PCR reactions; $1 \mu \mathrm{l}$ of the completed first-step PCR reaction mixtures was added to the second-step PCR reactions. For both PCR steps, PCR was initiated by denaturation for $5 \mathrm{~min}$ at $94^{\circ} \mathrm{C}$, followed by 40 cycles consisting of $30 \mathrm{~s}$ at $94^{\circ} \mathrm{C}, 30 \mathrm{~s}$ at $54^{\circ} \mathrm{C}$ and $45 \mathrm{~s}$ at $72^{\circ} \mathrm{C}$, and completed by a final extension of 5 min at $72{ }^{\circ} \mathrm{C}$. The amplification products $(8 \mu \mathrm{l})$ were visualized in $1.5 \%$ agarose Tris-acetate-EDTA gels stained with ethidium bromide (Sambrook et al. 1989).

\section{RESULTS AND DISCUSSION}

The GFPuv gene on the plasmid pBAD-GFPuv was chosen as a model to examine bacterial gene expression on beef carcass surfaces because it can be rapidly induced or repressed by arabinose and glucose, respectively (Guzman et al. 1995). Escherichia coli O157:H7, containing this plasmid, was inoculated onto the BCT surface at a level of $4.00 \times 10^{6} \mathrm{cfu} \mathrm{cm}^{-2}$. The arabinose and glucose solutions were applied to the tissue in a fashion analogous to that of the water and antimicrobial spray washes used by the meat slaughter industry to reduce the microbial load on carcasses. With the RT and nested PCR methods used, expression of $g f p u v$ was detected on beef tissue treated with both arabinose and glucose (Fig. 1). While repression of the $\mathrm{P}_{\mathrm{BAD}}$ promoter is very efficient, expression in the repressed state is typically not zero (Guzman et al. 1995). Detection of repressed gfpuv expression by E. coli $\mathrm{O} 157: \mathrm{H} 7$ on the glucose-treated BCT was probably due to the increased sensitivity gained by using a nested PCR procedure (Persing 1993). Nested PCR was used both to verify the specificity of the first-step amplicon and to increase the sensitivity of detection. Additional reasons for the choice of the GFPuv gene on pBAD-GFPuv in the current study are that it is both highly inducible and on a multi-copy plasmid (Guzman et al. 1995). The fact that repressed expression of $g f p u v$ could be detected is encouraging, as the detection of expression of single-copy genes will present a greater sensitivity challenge.

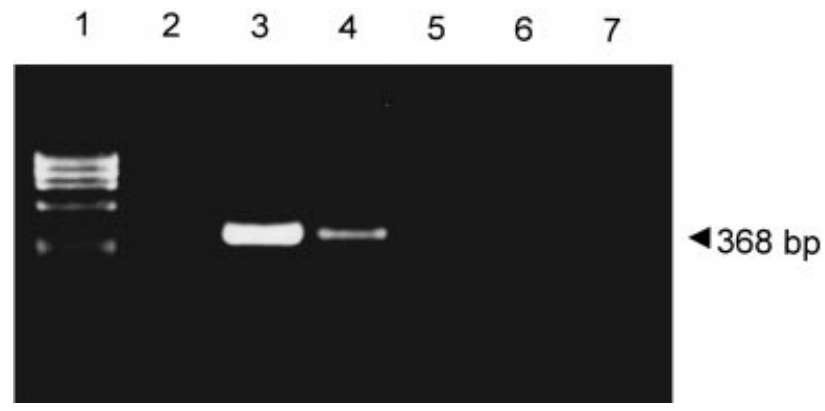

Fig. 1 Detection of GFPuv gene expression by Escherichia coli O157:H7 T1-1 on bovine carcass tissue (BCT). Gel analysis of amplification products from nested PCR of cDNA and DNasetreated RNA. Lane 1: molecular weight markers ( $\phi \mathrm{X} 174-H a e \mathrm{III}$ digest, Sigma); lane 2: cDNA from control (uninoculated) BCT; lane 3: cDNA from arabinose-treated BCT; lane 4: cDNA from glucose-treated BCT; lanes 5-7: DNase-treated RNA controls from control, arabinose-treated and glucose-treated BCT, respectively. Results shown are representative of triplicate experiments 
As the bacteria were inoculated onto the beef tissue surface, agitation by vigorous vortexing was examined as an alternative method to tissue homogenization for RNA isolation. Total RNA yields from $2 \times 2 \mathrm{~cm}$ BCT samples ranged from 160 to $270 \mu \mathrm{g}$ total RNA, reflecting the isolation of large amounts of bovine RNA in addition to bacterial RNA. To minimize any potential interference in the current study, the BCT was held at $-20^{\circ} \mathrm{C}$ for 1 week prior to use to allow degradation of any bovine RNA that may have sequence homology to the primers and be amplified in PCR reactions. Gel analysis of total RNA prior to RTPCR reactions showed typical degradation patterns for eukaryotic 18S and 28S rRNA subunits (data not shown). Bands for bacterial ribosomal $16 \mathrm{~S}$ and $23 \mathrm{~S}$ subunits were not visible and were probably obscured by the degraded bovine RNA. No amplification of bovine sequences in the uninoculated control RNA samples was observed (Fig. 1). Inclusion of uninoculated control tissue in these types of experiments should be adequate to identify any amplification of bovine sequences when fresh, pre-rigor tissue is used. In addition, the specificity of amplified sequences can be confirmed as the target sequences using internal probes or sequencing, or by nested PCR as done here.

The ability to detect changes in gene expression in situ is critical to the study of the physiological adjustments that bacteria make to adapt to stresses in their environment. Promoter-reporter gene fusions will be very important in providing a greater understanding of gene regulation under the different environmental conditions found in food processing (Aldsworth et al. 1998; Thompson et al. 1999). However, because of the genetic manipulations required, the use of this technique would typically preclude the examination of different isolates of the species of interest, which may be desirable because of different phenotypic characteristics among different wild-type strains. In addition, the technique of promoter-reporter gene fusions cannot be used for bacterial species for which there are no developed genetic systems. In contrast, the methods described here are readily amenable to the study of multiple strains of essentially any bacterial species. Because of its involvement in food-borne outbreaks associated with beef consumption and its current status as an adulterant in ground beef in the USA, E. coli $\mathrm{O} 157: \mathrm{H} 7$ was used as the demonstration bacterium. However, the RNA isolation protocol can be used as described for other Gram-negative bacterial species. Further work would be necessary to determine what procedural adjustments may be necessary to isolate RNA from Gram-positive bacteria on carcass surfaces (e.g. additional cell lysis step). In addition to RTPCR as described here, the RNA isolated by this procedure is appropriate for use in the quantification of specific mRNAs by Northern blot analysis, ribonuclease protection assays or quantitative RT-PCR procedures. Furthermore, the RNA can also be used for differential display or RNA arbitrarily primed PCR to detect and isolate bacterial genes, both known and previously undescribed, that are differentially expressed under various environmental conditions (Liang and Pardee 1992; Wong and McClelland 1994; Fislage et al. 1997; Fleming et al. 1998).

In conclusion, RNA isolation and RT-PCR procedures to examine bacterial gene expression on beef carcass surfaces were developed. The utility of these procedures was demonstrated by detecting transcription of mRNA of the GFPuv gene by E. coli $\mathrm{O} 157: \mathrm{H} 7$ on beef carcass surface tissue. Expression of $g f p u v$ was detected under conditions that both induce and suppress expression of the gene, indicating that this system may be adequately sensitive for detecting expression of single-copy genes. Knowledge of the genes that are induced when pathogens adapt and develop resistance to different food processing and preservation techniques will be a key to prohibiting the development of such resistances. The procedures described here should serve as useful tools for studying the genetic responses of bacteria upon exposure to the stresses imposed by the antimicrobial treatments applied to animal carcasses.

\section{REFERENCES}

Aldsworth, T.G., Sharman, R.L., Dodd, C.E.R. and Stewart, G.S.A.B. (1998) A competitive microflora increases the resistance of Salmonella typhimurium to inimical processes: evidence for a suicide response. Applied and Environmental Microbiology 64, 1323-1327.

Archer, D.L. (1996) Preservation microbiology and safety: evidence that stress enhances virulence and triggers adaptive mutations. Trends in Food Science and Technology 7, 91-95.

Arnold, K.W. and Kaspar, C.W. (1995) Starvation- and stationary-phase-induced acid tolerance in Escherichia coli $\mathrm{O} 157: \mathrm{H7}$. Applied and Environmental Microbiology 61, 2037-2039.

Bunning, V.K., Crawford, R.G., Tierney, J.T. and Peeler, J.T. (1990) Thermotolerance of Listeria monocytogenes and Salmonella typhimurium after sublethal heat shock. Applied and Environmental Microbiology 56, 3216-3219.

Cheville, A.M., Arnold, K.W., Buchrieser, C., Cheng, C.-M. and Kaspar, C.W. (1996) RpoS regulation of acid, heat, and salt tolerance in Escherichia coli $\mathrm{O} 157: \mathrm{H} 7$. Applied and Environmental Microbiology 62, 1822-1824.

Crameri, A., Whitehorn, E.A., Tate, E. and Stemmer, W.P.C. (1996) Improved green fluorescent protein by molecular evolution using DNA shuffling. Nature Biotechnology 14, 315-319.

Farber, J.M. and Brown, B.E. (1990) Effect of prior heat shock on heat resistance of Listeria monocytogenes in meat. Applied and Environmental Microbiology 56, 1584-1587.

Fislage, R., Berceanu, M., Humboldt, Y., Wendt, M. and Oberender, H. (1997) Primer design for a prokaryotic differential display RT-PCR. Nucleic Acids Research 25, 1830-1835.

Fleming, J.T., Yao, W.-H. and Sayler, G.S. (1998) Optimization of differential display of prokaryotic mRNA: application to pure 
culture and soil microcosms. Applied and Environmental Microbiology 64, 3698-3706.

Gahan, C.G.M., O'Driscoll, B. and Hill, C. (1996) Acid adaptation of Listeria monocytogenes can enhance survival in acidic foods and during milk fermentation. Applied and Environmental Microbiology 62, 3128-3132.

Guzman, L.-M., Belin, D., Carson, M.J. and Beckwith, J. (1995) Tight regulation, modulation, and high-level expression by vectors containing the arabinose $\mathrm{P}_{\mathrm{BAD}}$ promoter. Fournal of Bacteriology 177, 4121-4130.

Hengge-Aronis, R., Klein, W., Lange, R., Rimmele, M. and Boos, W. (1991) Trehalose synthesis genes are controlled by the putative sigma factor encoded by rpoS and are involved in stationary phase thermotolerance in Escherichia coli. Fournal of Bacteriology 173, 7918-7924.

Knøchel, S. and Gould, G. (1995) Preservation microbiology and safety: quo vadis? Trends in Food Science and Technology 6, 127131.

Leyer, G.J. and Johnson, E.A. (1992) Acid adaptation promotes survival of Salmonella spp. in cheese. Applied and Environmental Microbiology 58, 2075-2080.

Leyer, G.J. and Johnson, E.A. (1993) Acid adaptation induces cross-protection against environmental stresses in Salmonella typhimurium. Applied and Environmental Microbiology 59, 18421847.

Leyer, G.J., Wang, L.-L. and Johnson, E.A. (1995) Acid adaptation of Escherichia coli $\mathrm{O} 157: \mathrm{H} 7$ increases survival in acidic foods. Applied and Environmental Microbiology 61, 3752-3755.

Liang, P. and Pardee, A.B. (1992) Differential display of eukaryotic messenger RNA by means of the polymerase chain reaction. Science 257, 967-971.

Mackey, B.M. and Derrick, C.M. (1986) Elevation of the heat resistance of Salmonella typhimurium by sublethal heat shock. Fournal of Applied Bacteriology 61, 389-393.
Mackey, B.M. and Derrick, C.M. (1987) Changes in the heat resistance of Salmonella typhimurium during heating at rising temperatures. Letters in Applied Microbiology 4, 13-16.

McCann, M.P., Kidwell, J.P. and Matin, A. (1991) The putative $\sigma$ factor KatF has a central role in the development of starvation-mediated general resistance in Escherichia coli. Fournal of Bacteriology 173, 4188-4194.

Mekalanos, J.J. (1992) Environmental signals controlling expression of virulence determinants in bacteria. Fournal of Bacteriology 174, 1-7.

Persing, D.H. (1993) In vitro nucleic acid amplification techniques. In Diagnostic Molecular Microbiology, Principles and Applications ed. Persing, D.H., Smith, T.F., Tenover, F.C. and White, T.J. pp. 51-87. Washington, D.C.: American Society for Microbiology.

Rees, C.E.D., Dodd, C.E.R., Gibson, P.T., Booth, I.R. and Stewart, G.S.A.B. (1995) The significance of bacteria in stationary phase to food microbiology. International Fournal of Food Microbiology 28, 263-275.

Sambrook, J., Fritsch, E.F. and Maniatis, T. (1989). Molecular Cloning: a Laboratory Manual 2nd edn. New York: Cold Spring Harbor Laboratory Press.

Sheridan, J.J. and McDowell, D.A. (1998) Factors affecting the emergence of pathogens on foods. Meat Science 49, S151-S167.

Thompson, J.M., Stewart, G.S.A.B. and Dodd, C.E.R. (1999) RpoS function in Salmonella Typhimurium LT2 monitored in a skim milk model food. Fournal of Food Protection 62, 70-72.

Wang, G. and Doyle, M.P. (1998) Heat shock response enhances acid tolerance of Escherichia coli O157:H7. Letters in Applied Microbiology 26, 31-34.

Wong, K.K. and McClelland, M. (1994) Stress-inducible gene of Salmonella typhimurium identified by arbitrarily primed PCR of RNA. Proceedings of the National Academy of Science USA 91, 639-643. 